Magdalena ZAWADZKA

(Warszawa, UW)

\title{
KILKA UWAG O WCZESNOCHRZEŚCIJAŃSKIEJ KRYTYCE RZYMSKICH WIDOWISK
}

(Na podstawie: De spectaculis Tertuliana, De spectaculis Nowacjana, De gubernatione Dei VI Salwiana z Marsylii)

„Nihil ferme vel criminum vel flagitiorum est, quod in spectaculis non sit"1

Wszelkiego typu widowiska stanowiły bardzo istotny element rzeczywistości społecznej i politycznej cesarskiego Rzymu a organizowane pod byle pretekstem ludi circenses, munera gladiatoria czy ludi scaenici ściągały do cyrków, amfiteatrów i teatrów thumy spragnione niewybrednej, ale za to darmowej rozrywki ${ }^{2}$. Taki sposób spędzania wolnego czasu nie cieszył się uznaniem ludzi wykształconych, o czym świadczyć mogą słowa Seneki:

„Nihil vero tam damnosum bonis moribus quam in aliquo spectaculo desidere; tunc enim per voluptatem facilius vitia subrepunt"”.

To co dla Seneki było przede wszystkim sprawą etyki i estetyki, dla autorów wczesnochrześcijańskich stanowiło już problem wiary i nie lada wyzwanie duszpasterskie. Należało bowiem odwieść wiernych od udziału w widowiskach pogańskich, nie mogąc równocześnie całkowicie wypełnić powstałej w tym miejscu luki. Wykształceni chrześcijanie bowiem rezygnując $z$ tego, co oferowała pogańska kultura wysoka, mieli do dyspozycji coraz lepiej się rozwijającą literaturę chrześcijańską, prości zaś amatorzy igrzysk i mimów na takie zamienniki liczyć nie mogli.

Najsłynniejszym chyba i najczęściej cytowanym utworem chrześcijańskim skierowanym przeciwko uczestnictwu wyznawców Chrystusa w widowiskach jest traktat $D e$ spectaculis napisany pod koniec II wieku przez Tertuliana ${ }^{4}$, nazywanego przez niektórych współczesnych badaczy ojcem niechęci Kościoła

1 Salvianus Massiliensis, De gubernatione Dei VI 10, SCh 220, 366.

2 Por. J. Carcopino, Życie codzienne w Rzymie w okresie rozkwitu cesarstwa, tłum. M. Pąkcińska Warszawa 1966, 196-236.

${ }^{3}$ Epistula 7, 2. Z niechęcią do igrzysk odnosił się także Pliniusz Młodszy, który w liście IX 6 pisal: „Circenses erant, quo genere spectaculi ne levissime quidem teneor. Nihil novum, nihil varium, nihil, quod non semel spectasse sufficiat".

${ }^{4}$ Por. De spectaculis, ed. E. Dekkers, CCL 1, 227-253, tłum. W. Myszor, PSP 5, Warszawa 1970, 79-113. 
wobec teatru ${ }^{5}$. Około poł. III wieku powstało przypisywane obecnie Nowacjanowi, a zachowane pod imieniem Cypriana kolejne dziełko zatytułowane $D e$ spectaculis $^{6}$, omawiające tę samą problematykę, z którą 50 lat wcześniej zmierzyl się Tertulian. W niniejszym artykule zajmiemy się jeszcze jednym tekstem dotyczącym widowisk, który mimo, iż nie jest odrębnym traktatem, objętością i kompozycją nie ustępuje pismom Tertuliana i Nowacjana, a mamy tu na myśli VI księgę De gubernatione Dei Salwiana z Marsylii ${ }^{7}$. Nie brakuje oczywiście i u innych łacińskich autorów wczesnochrześcijańskich wzmianek na temat widowisk $^{8}$, ograniczymy się jednak tylko do wyżej wspomnianych utworów, gdyż szczegółowe przebadanie wszystkich łacińskich dzieł antyku chrześcijańskiego pod kątem ich stosunku do igrzysk i przedstawień znacznie przekroczyloby ramy tego artykułu.

$\mathrm{Na}$ pierwszy rzut oka dziwić może dobór tekstów tak odległych od siebie w czasie; od powstania dzieła Tertuliana do napisania De gubernatione Dei Salwiana upłynęło bowiem bez mała 250 lat i nie trzeba być wybitnym znawcą historii tamtego okresu, by zdawać sobie sprawę, jak wiele w tym czasie dokonało się przemian zarówno w Kościele, jak i w całym Cesarstwie. Rzeczywiście, gdybyśmy mieli do czynienia $z$ tekstami od siebie niezależnymi, pisanymi jedynie na podstawie doświadczeń autorów, znalezienie wspólnej płaszczyzny dla ich analizy byłoby bardzo trudne, jednakże utwory Tertuliana, Nowacjana i Salwiana są ze sobą ściśle powiązane i w każdym następnym odnajdujemy echa poprzednich ${ }^{9}$, co pozwala przypuszczać, że w przypadku Nowacjana i Salwiana są raczej efektem siedzenia w bibliotece, niż na widowni amfitea$\mathrm{tru}^{10}$. Nie odbiera to nam jednak przyjemności czytania, gdyż u naszych autorów wykształcenie retoryczne idzie $w$ parze $z$ porywczą naturą i niemałym temperamentem, więc argumenty, chociaż podobne, $\mathrm{u}$ każdego $\mathrm{z}$ nich brzmią trochę inaczej. Nie bez wpływu pozostaje też charakter poszczególnych utworów; pi-

5 Por. V. Power, Tertullian: Father of Clerical Animosity toward the Theatre, „Educational Theatre Journal" 23 (1971) 36-50.

6 Por. De spectaculis, ed. G.F. Diercks, CCL 4, 167-179, przekład zbiorowy, „Meander” 57 (2002) 69-75 ; A. Kwaczek, "De spectaculis" Nowacjana - kompozycja, wzorce, odniesienia, tamże, s. 77-85; M. Eder, Traktat Nowacjana „O widowiskach" - kilka uwag o tekście $i$ autorze, tamże, s. 59-68.

7 Por. De gubernatione Dei VI, ed. G. Lagarrigue, SCh 220, 358-429.

${ }^{8}$ Wystarczy wspomnieć tu chociażby Expositio psalmi CXVIII (5, 28, PL 15, 1327-1328, lub CSEL 62, 97) Ambrożego z Mediolanu czy Confessiones Augustyna, w których m.in. czytamy: „gurges tamen morum Carthaginiensium, quibus nugatoria fervent spectacula, absorbuerat eum insania circensium" (VI 7, CCL 27, 80-81).

${ }^{9} \mathrm{O}$ wpływie twórczosci Tertuliana na Salwiana z Marsylii por. J. Waltzing, Tertullien et Salvien, „Le Musée Belge” 19 (1920) 39-43.

${ }^{10}$ W przypadku Salwiana możemy z całą pewnością stwierdzić, że wiadomości dotyczące walk gladiatorów czerpal z wcześniejszych pism, gdyż w czasie, gdy powstawało jego dzieło De gubernatione, munera gladiatoria były już w całym Cesarstwie zakazane. 
smo Tertuliana to traktat praktyczno-ascetyczny, De spectaculis Nowacjana ma charakter listu pasterskiego, zaś De gubernatione Dei Salwiana jest dziełem historycznym $\mathrm{z}$ wyraźnie zarysowaną tezą teologiczną, której podporządkowany jest również passus o widowiskach. Przejdźmy zatem do analizy treści omawianych utworów, a przekonamy się, że cum tres faciunt idem, non est idem.

Głównym zarzutem wysuwanym przeciwko widowiskom, a w szczególności igrzyșkom cyrkowym, jest ich scisły związek $z$ religią pogańską i uroczysta oprawa na każdym kroku związek ten podkreślająca ${ }^{11}$. Tertulian w rozdziałach V i VI swego traktatu bardzo skrupulatnie przedstawia pochodzenie i nazwy poszczególnych świąt i związanych $z$ nimi igrzysk po to, by wreszcie te obszerne wywody następująco skonkludować:

„Sed de idolatria nihil differt apud nos, sub quo nomine et titulo, dum ad eosdem spiritus perveniat, quibus renuntiamus. Licebit mortuis, licebit deis suis faciant, perinde mortuis suis ut diis faciunt; una condicio partis utriusque est, una idolatria, una renuntiatio nostra adversus idolatrian"12.

Następnie, w VII rozdziale opisuje oprawę i przepych towarzyszące rozpoczęciu igrzysk, rozdział natomiast VIII poświęca opisowi cyrku, gdzie „singula ornamenta circi singula templa sunt"13. Przekonuje przy tym współwyznawców:

„Animadverte, Christiane, quot nomina inmunda possederint circum. Aliena est tibi regio, quam tot diaboli spiritus occupaverunt"14.

W rozdziale IX $\mathrm{z}$ kolei przechodzi do omówienia przedstawień teatralnych (ludi scaenici), i jak w przypadku igrzysk zaczyna od ich proweniencji, opisując miejsce, w którym się odbywają $\mathrm{i}$ dowodząc, że teatr też nie jest wolny od grzechu idolatrii, albowiem "theatrum proprie sacrarium Veneris est" ${ }^{\text {15 }}$. Rozdziały wreszcie XI i XII poświęca odpowiednio zawodom sportowym i walkom gladiatorów ${ }^{16}$. Jak mogliśmy zauważyć, Tertulian w rozdziałach V-XII przedstawia pełny przegląd widowisk z podziałem na poszczególne kategorie, zwracając baczną uwagę na tkwiące w nich elementy bałwochwalstwa. Uznanie budzi jasność i rzetelność Tertulianowego wywodu, popartego także wiadomościami zaczerpniętymi $\mathrm{z}$ dzieł autorów pogańskich ${ }^{17}$.

Smiało możemy stwierdzić, że opinie pozostałych dwóch autorów na temat przejawów pogańskiego kultu we wszystkich typach widowisk są zbieżne

11 Opis uroczystej procesji rozpoczynającej wyścigi rydwanów możemy przeczytać m.in. u Owidiusza w Amores III 2.

12 Tertullianus, De spectaculis 6, 4, CCL 1, 233.

13 Tamże 8, 3, CCL 1, 234.

14 Tamze 8, 7, CCL 1, 234.

15 Tamze 10, 3, CCL 1, 236.

${ }^{16}$ Por. tamże 11-12, CCL 1, 237-239.

17 Por. tamże 5, 1-2, CCL 1, 231-232. 
z poglądami Tertuliana, chociaż nie zostały przez nich tak wyczerpująco przedstawione; posłuchajmy zatem Nowacjana:

„Quod enim spectaculum sine idolo, quis ludus sine sacrificio, quod certamen non consecratum mortuo? Quid inter haec Christianus fidelis facit, si idolatriam fugit? ${ }^{18}$.

Salwian natomiast bałwochwalstwu poświęca znacznie mniej uwagi, niż jego poprzednicy, w swym dziele skupia się bowiem przede wszystkim na upadku obyczajów, który, według niego, jest między innymi obrazowany przez stosunek do igrzysk. Znamienne jest to, że w De gubernatione Dei ani razu nie występuje wyraz idolatria, podczas gdy u Tertuliana w De spectaculis występuje on aż 25 razy $^{19}$, zaś w utworze Nowacjana sześciokrotnie ${ }^{20}$. Nie może tu być argumentem wyjaśnienie, że w czasach Salwiana termin ten wyszedł już $\mathrm{z}$ użycia, albo, że nasz autor $\mathrm{z}$ sobie tylko znanych powodów wcale go nie używał, gdyż w jego dziele Ad Ecclesiam słowo to występuje dwukrotnie ${ }^{21}$. Wzmianki na temat bałwochwalstwa są u Salwiana mniej liczne i prawdopodobnie inspirowane lekturą Tertuliana i Nowacjana ${ }^{22}$. Pisał on bowiem:

„Dubium enim non est quod laedunt deum utpote idolis consecratae. Colitur namque et honoratur Minerva in gymnasiis, Venus in theatris, Neptunus in circis, Mars in harenis, Mercurius in palaestris, et ideo pro qualitate auctorum cultus est superstitionum: quicquid immunditiarum est, hoc exercetur in theatris, quicquid luxuriarum in palaestris, quicquid immoderationis in circis, quicquid furoris in caveis" 23 .

Zastanówmy się chwilę nad przyczynami, dla których Tertulian tyle miejsca i energii poświęcił śledzeniu i piętnowaniu idolatrii w każdym niemal elemencie widowisk publicznych, natomiast Salwian mógł sobie pozwolić na jedynie zdawkowe o niej wspomnienie. Otóż odbiorcy dzieł Tertuliana żyli jeszcze w świecie w dużej mierze pogańskim, w którym ciągła obecność rzymskich bóstw i ich kultów była na porządku dziennym; traktowali je po prostu jako stały, choć niezbyt groźny element rzeczywistości; aby zmienić to podejście, należało, jak to uczynił Tertulian, przy pomocy systematycznego wykładu nadać właściwą rangę pomijanym i niedostrzeganym dotąd zjawiskom, nazywając niektóre rzeczy po imieniu, oraz wytłumaczyć, że to, co uchodzi powszechnie za niewinną rozrywkę, jest grzechem. Salwian natomiast nie musiał

${ }^{18}$ Novatianus, De spectaculis $4,2, \mathrm{CCL} 4,171$, gdzie znajdujemy też informacje historyczne, wzorowane najprawdopodobniej na Tertulianie.

${ }^{19}$ Por. G. Claesson, Index Tertullianeus, II, Paris 1975, 705.

20 Por. Index nominum, verborum et locutionum [Novatiani], CCL 4, 318.

21 Por. L. Rochus, La latinité de Salvien, Bruxelles 1934, 17.

22 Por. Walzing, s. 40-42.

23 Salvianus, De gubernatione Dei VI 60, SCh 220, 400-402. 
się już zmagać z takimi kwestiami, gdyż swe dzieło tworzył w czasach, gdy to chrześcijaństwo było już religią panującą, a pozostałości dawnych kultów stanowiły jedynie relikt minionej epoki. Od stwierdzenia obecności elementów pogańskiego kultu w widowiskach, niedaleka jest droga do zamieszania w nie diabła, który, zdaniem autorów, zapewne znacznie skuteczniej oddziaływał na wyobraźnię wiernych, niż nie tak znowu groźnie wyglądające, oswojone przez literaturę i sztukę bóstwa pogańskie. Nasi autorzy podkreślają przewrotność zła, które, dzięki temu, że jest zmieszane z przyjemnością, łatwiej ogarnia dusze nieświadomych widzów ${ }^{24}$; zauważmy, jak bardzo jest to zbieżne z przytoczonymi we wstępie refleksjami Seneki.

Elementem obecnym we wszystkich omawianych przez nas tekstach jest rozumienie udziału $\mathrm{w}$ przedstawieniach $\mathrm{w}$ kategoriach sprzeniewierzenia się chrześcijaństwu, oraz pozostawienia Chrystusa na rzecz diabła. Tertulian z właściwą sobie skrupulatnością dowodzi, że formuła chrzcielna, w której jest mowa o wyrzeczeniu się diabła, odnosi się do idolatrii, a co za tym idzie, do widowisk:

„Cum aquam ingressi Christianam fidem in legis suae verba profitemur, renuntiasse nos diabolo et pompae et angelis eius ore nostro contestamur. Quid erit summum atque praecipuum, in quo diabolus et pompae et angeli eius censeantur, quam idolatria? (...) igitur si ex idolatria universam spectaculorum paraturam constare constiterit, indubitate praeiudicatum erit etiam ad spectacula pertinere renuntiationis nostrae testimonium in lavacro, quae diabolo et pompae et angelis eius sint mancipata, scilicet per idolatrian"25.

Widzimy, jak starannie przeprowadzony jest ten wywód, Tertulian unika tu wszelkich niedopowiedzeń i skrótów myślowych tak, by nawet niezbyt biegły w filozoficznych spekulacjach czytelnik, prowadzony za rękę, krok po kroku doszedł do tych samych wniosków. Nowacjan zaś rezygnuje z przedstawiania nam pełnego toku rozumowania, zadowalając się jedynie wnioskiem:

„Et cum semel illi renuntiando rescissa sit res omnis in baptismate, dum post Christum ad diaboli spectaculum vadit, Christo tamquam diabolo renuntiat" ${ }^{26}$.

Najciekawiej rozwiązał tę kwestię Salwian, który, by wydatnie wzmocnić siłę swoich argumentów, ucieka się do pewnej manipulacji modyfikując treść

${ }^{24}$ Tertullianus, De spectaculis 27, 4, CCL 1, 250: „nemo venenum temperat felle et elleboro, sed conditis pulmentis et bene saporatis, et plurimum dulcibus id mali inicit. Ita et diabolus letale quod conficit rebus dei gratissimis et acceptissimis imbuit"; Novatianus, De spectaculis 4, 4, CCL 4, 171-172: „Idolatria, ut iam dixi, ludorum omnium mater est, quae, ut ad se Christiani veniant, blanditur illis per oculorum et aurium voluptatem [...]. Ita diabolus artifexquia idolatriam per se nudam sciebat horreri, spectaculis miscuit, ut per voluptatem posset amari".

25 Tertullianus, De spectaculis $4,1-3$, CCL $1,231$.

${ }^{26}$ Novatianus, De spectaculis $4,3, \mathrm{CCL} 4,171$. 
formuły chrzcielnej ${ }^{27}$, uwalnia się w ten sposób od konieczności drobiazgowego dowodzenia swoich racji, a jednocześnie uzyskuje znacznie mocniejszy efekt, niż rezygnujący $\mathrm{z}$ takich sztuczek Tertulian. Biskup bowiem pisał:

„In spectaculis enim apostatio quaedam fidei est, et a symboli ipsius et caelestibus sacramentis letalis praevaricatio. Quae est enim in baptismo salutari Christianorum prima confessio? Quae scilicet nisi ut renuntiare se diabolo ac pompis eius et spectaculis atque operibus protestentur? Ergo spectacula et pompae etiam iuxta nostram professionem opera sunt diaboli" ${ }^{28}$.

We wstępie do niniejszego artykułu pisaliśmy, że kultura chrześcijańska nie stworzyla w pierwszych wiekach swego istnienia żadnej alternatywy dla publicznych widowisk. Nie znaczy to jednak, że nasi autorzy nie proponowali chrześcijanom, którzy zrezygnują $\mathrm{z}$ uczestnictwa $\mathrm{w}$ pogańskich uroczystościach, niczego w zamian. I tak Nowacjan zachęca do kontemplowania piękna wschodów i zachodów słońca, zmiennego uroku gwiazd, a także nieprzebranego bogactwa przyrody, z którym nie może się równać żadne dzieło człowieka, wykazując przy tym, jak wiele opowieści znacznie ciekawszych od tych wystawianych w teatrach, można znaleźć w Biblii:

„Scripturis, inquam, sacris incumbat christianus fidelis: ibi inveniet condigna fidei spectacula" ${ }^{29}$.

Tertulian zaś każe współwyznawcom szukać przyjemności w wierze, prawdziwej wolności, jaką może dać tylko pogarda dla świata doczesnego, oraz w czystym sumieniu, albowiem ,haec spectacula Christianorum sancta perpetua gratuita"30. Warto odnotować, że stosuje przy tym frazeologię żywcem przeniesioną z opisów igrzysk, mamy tu zwroty „cursus saeculi intuere”, „metas consummationis exspectare", ,societates ecclesiarum defenere", co ma być alternatywą dla miłośników wyścigów rydwanów. Zwolennikom przedstawień i literatury pogańskiej proponuje zwrócenie się ku dziełom autorów chrześcijańskich, które mają tę przewagę nad pogańskimi odpowiednikami, że głoszą prawdę. Amatorzy zaś walk pięściarskich i zapasów mogą podziwiać zmagania bezwstydu z czystością, czy okrucieństwa z miłosierdziem. Passus ten kończy się bardzo

${ }^{27}$ Co ciekawe, w analogicznych formułach cytowanych przez innych autorów nie występują spectacula; i tak u Ambrożego (Hexameron I 4) mamy: „Abrenuntio tibi, diabole, et operibus tuis et imperiis tuis"; w dzielku Praedestinatus $(3,7)$ czytamy: „abrenuntio omnibus pompis diaboli et voluptatibus eius”; Cezary z Arles zaś (Sermo 12,4) pisze: „Quando enim interrogatus est: «Abrenuntias diabolo, pompis et operibus eius»? [...]”. Jak widać z powyższych przykladów, formuła wyrzeczenia się diabla nie miała sztywno ustalonej treści i dopuszczala lekkie modyfikacje i rozwinięcia, co wykorzystal Salwian, by zyskać bardzo mocny argument przeciw przedstawieniom.

${ }^{28}$ Salvianus, De gubernatione Dei VI 31, SCh 220, 382.

${ }^{29}$ Novatatianus, De spectaculis $10,1, \mathrm{CCL} 4,178$.

30 Tertullianus, De spectaculis 29, 3, CCL 1, 251. 
mocnym akcentem, którym są słowa skierowane do spragnionych widoku krwi na arenie amfiteatru: „vis autem sanguinis aliquid? Habes Christi”31.

Dwa z omawianych przez nas utworów wieńczy motyw Sądu Ostatecznego jako wspaniałego, wielkiego i przyćmiewającego wszystko widowiska. O ile Nowacjan traktuje ten temat dość zdawkowo, to Tertulian daje się ponieść temperamentowi i wykorzystuje tę okazję, by raz jeszcze rozprawić się ze światem pogańskim. Wyraźnie rozkoszuje się wizją wielkich tego świata trawionych piekielnym ogniem. Z ironią przedstawia ich zaskoczenie, gdy zamiast przed trybunałem Radamantysa i Minosa, stają przed obliczem Chrystusa. Nie tylko poganie stają się aktorami tego przejmującego spektaklu, bo Tertulian, zapędziwszy się w swej polemicznej pasji, włącza weń też Samarytan, którzy muszą ponieść karę za wszelkie krzywdy wyrządzone Chrystusowi. Warunkiem, jaki trzeba spełnić, by móc cieszyć oczy tym widowiskiem nad widowiskami jest wyrzeczenie się marnych jego namiastek organizowanych przez pretorów, konsulów, kwestorów czy kapłanów ${ }^{32}$.

Trudno $\mathrm{z}$ całą pewnością stwierdzić, na ile stopniowy spadek zainteresowania widowiskami był wynikiem podobnych polemik, podejmowanych przez najwybitniejsze umysły tamtych czasów. Argumenty te zapewne nie pozostawały bez wpływu na decyzje chrześcijańskich władców, którzy najpierw znacznie ograniczali zasięg najkrwawszych typów widowisk po to, by wreszcie całkowicie ich zakazać ${ }^{33}$. Faktem natomiast jest, że pogańskie igrzyska w swym dawnym kształcie, jako nieodłączny element rzymskiego świata, musiały wraz $\mathrm{z}$ tym światem ustąpić miejsca nowej rzeczywistości.

\section{QUEM IN MODUM AUCTORES VETERES CHRISTIANI SPECTACULA REPREHENDERINT \\ [De spectaculis Tertulliani, De spectaculis Novatiani, De gubernatione Dei VI Salviani Massiliensis]}

\section{(Argumentum)}

Hac in dissertatione de tribus commentationibus, quae sunt Tertulliani De spectaculis, Novatiani De spectaculis atque Salviani Massiliensis De gubernatione Dei liber sextus, disputatur necnon animus auctorum christianorum veterum erga circenses, munera ludosque scaenicos, qualis fuerit, multis exemplis demonstratur.

${ }^{31}$ Tamże 29, 5, CCL 1, 252.

32 Por. Novatianus, De spectaculis 10, CCL 4, 178-179; Tertullianus, De spectaculis 30 , CCL 1 , 252-253.

${ }^{33} \mathrm{Na}$ Wschodzie kres walk gladiatorów datuje się na koniec IV wieku, na Zachodzie zaś munera zostaly zniesione edyktem Honoriusza w 404 roku. 